\title{
Radiographical Evaluation of Bone Resorption Around Fixed Prosthodontics
}

\author{
Jabbar Hussein Kamel ${ }^{1}$ and Faraed Dawood Salman ${ }^{2 *}$ \\ ${ }^{1}$ Professor of Conservative Dentistry, Head of Conservative Department, Ishik \\ University, Erbil, Iraq \\ ${ }^{2}$ Assistant Professor, Department of Dental Assistant, Medical Dental University, \\ Hawler Erbil Poly Technique University, Iraq \\ *Corresponding Author: Faraed Dawood Salman, Professor of Conservative \\ Dentistry, Head of Conservative Department, University of TIU, Erbil, Iraq.
}

Received: April 17, 2020

Published: June 01, 2020

(C) All rights are reserved by Faraed Dawood

Salman and Jabbar Hussein Kamel.

\begin{abstract}
Aim of the Study: This study designed for find radiographical assessment of bone resorption around abutment teeth of fixed bridge construction with the relation effects of age, number of missing area sex and arch.

Background: Fixed dental bridge, it is fixed prosthetic restoration used to reestablish one or more lost teeth and placed on abutment which is natural teeth.

Materials and Methods: In the recent study, the samples were collected randomly from patients who had fixed dental bridge and attended oral diagnosis and radiology department in college of Tishik International University, in Erbil during the period between “October 2018 - March 2019”. At first questioners had been filled for those patients who had posterior dental fixed bridge either they were(metal or dental PFM or zircon) all were either single missed or double missed teeth in molar and premolar region, the questioner included two age groups which were between (20 - 39) - (40 - 60) years name, age, gender, number of missing unit, and location of fixed dental bridge were recorded, and radiographs were viewed on computer and measurement done for all the radiographs by NEWTOM program.

Results: In this study 242 cases were recorded from total number of cases which had been done. There were $44.8 \%$ male and $55.2 \%$ female. According to age group (20 - 39) was 16.2\% and (40 - 60) years 83.8\% according to missing unit, one missing unit 65.6\%, two missing unit 34.4\% according to the site of the bridge, upper right $29.9 \%$, upper left 30.7\%, lower left $14.5 \%$, lower right $24.9 \%$. According to non-bridge site, upper right 21.6\%, upper left 2.4\%, lower left 39.8\%, lower right $26.1 \%$.

Conclusion: According to this study, bone resorption comparison between bridge site and non-bridge side, significant and higher rate of bone resorption had been recorded in non-bridge side.
\end{abstract}

Keywords: Radiographic Evaluation; Bone Resorption; Fixed Prosthesis

\section{Introduction}

Missing teeth can be supplanted with fixed prostheses that will enhance patient upgrade quiet solace and masticatory limit, keep up the wellbeing and honesty of the dental arches, and in numerous cases, raise the patient's mental self-portrait. It is likewise possible, using fixed dental prosthetic and to render an ideal occlusion that improves the orthopedic dependability of the tempor0mandibular joints (TMJs). Then again, with inappropriate treatment of the occlusion, it is possible to make disharmony and harm to the stomatognathic framework. In dentistry, Ante's law refers to a gathering of recommendations identified with crown-to-root proportion set forth by Irwin H. Risk, in a proposition paper he wrote in 1926 [1]. Fixed prosthodontics is worried about reestablishing teeth utilizing rebuilding efforts that are fixed inside patient's oral cavity. They are generally formed or reconstruct in a lab, by taking impressions (molds) for the professional technician to work with. They are otherwise called "indirect restoration" [2].

Ante's law hypothesized: that "total area of abutment teeth should be in uniform manner or more than area of tooth or teeth should be replaced" Working from this reason, later cases were 
made that: "the total length of attachments of the periodontal membrane of the abutment tooth should be somewhere around one half to two third of that of its typical root attachment". It was given to be reasoned the Ante's law as for teeth has been refuted [3].

Contraindications: Dimension of saddle area excessively too long [4]. Patients with para function e.g. bruxism [4]. Poor patient inspiration. Dynamic dental infection (caries, periodontal malady) and unfortunate oral clearance [5].

Case selection: The existence rate of dental bridge might be influenced by the length of span, exact location of bridge, shape and the size, number and condition of prepared abutment teeth [6]. Besides, any active sickness including caries or periodontal disease should be treated and followed in order to maintain and ensure patient consistence in keeping up suitable oral hygiene $[7,8]$.

Selection and evaluation of abutment teeth: Ante's law, is pericemental area of abutment teeth should be equal or more than pericemental area of tooth or teeth that should be replaced [9] the distance from the occlusal/incisor surface of the tooth to the alveolar crest in relation to the length of root within the bone is called crown to root proportion is. The lowest proportion of crown to root is considered to be $1: 1$; the most satisfactory is a crown: root of 2:3. As the proportion of tooth reinforced by bone reductions [5].

\section{Bridge failures}

Inadequate oral clearance: Patient with fixed dental prosthesis containing bridges, maintaining good oral hygiene to prevent plaque formation around the bridge is important. the gingival health round the fixed bridges subsequently 14-day, 6 month after insertion exposed that the surface were additional plaque retaining, and cause gingival inflammation without regard the material of fabrication of the bridge, different single crown which didn't confirm the same affect $[10,11]$.

Periodontal disease: It may be imagined to make a bigger bridge, or the abutment teeth might be decreased and utilized as abutments for an over-denture. Teeth that have missing so much help that they are not suitable as bridge abutments are likewise not suitable also as abutments for conventional dentures [12].

Previous study: Ante's law expresses that "total periodontal area of abutment teeth should be equal or more than tooth or teeth that should be replaced "for over 80 years, this law has been educat- ed in standard course readings of prosthodontics as a significant condition affecting FDP design. If Ante's law has appeared at being proof based, at the point the alternative of an FDP upheld by abutment with patients and clinicians to consider. With well-kept up, healthy periodontal tissue support, FDPs not fulfilling Ante's law have survival rates of FDPs that do fulfill Ante's law. Accordingly, the plan of an FDP does not really need to fulfill Ante's law.

\section{Materials and Methods}

In our study, the samples were collected randomly from patients who had bridge and attended to diagnosis and oral radiology department in college of dentistry of Tishik International University, in Erbil during the period between October 2017 - March 2018. The collection of the samples have been arranged according to questionnaires, two age group which were between (20 - 39) and (40 - 60) which has been made (Figure 1 and 2) which include personal information related to name patient, gender, and number of missing tooth or teeth that replaced by dental bridge in posterior region and location of bridge.

The radiographs were taken by Orthopantogram (Figure 3) in diagnosis and oral radiology department and after that by using New Tom program (Figure 4 and 5) measurements of bone resorption between CEJ to crest of alveolar bone had been measured for bridge side and non-bridge side (Figure 6-9) after that printed out and bounded with our questioners and all X-rays were evaluated by three examiner.

Data management and statistical analysis

Data will be recorded on a specially designed questionnaire (Figure 1 and 2), collected and entered in the computer and then analyzed using appropriate data system which is called statistical package for social science (SPASS) version 24 and the results will be compared between patients with different variables, with a statistical significance level of $<0.05$. The results will be presented as rates, ratios, frequencies and percentages in tables, figures and analyzed using, chi-square test.

\section{Materials}

\section{Orthonpantogram: NEWTOM}

- $\quad$ Plant: VIA BI COCCA 14/C-40026 IMOLA (BO) ITALY

- $\quad$ CEPH ARM NEWTOM GIANO

- $\quad 90 \mathrm{kvp} / 10 \mathrm{~mA} \max$

- Focal spot: $0.5 \mathrm{~mm}$. 


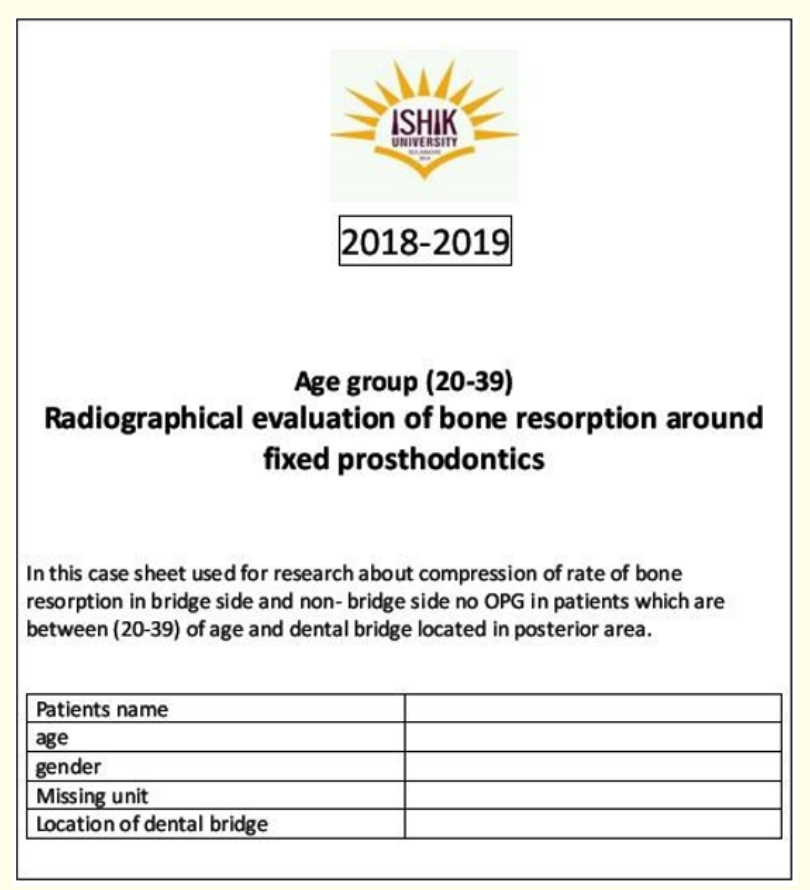

Figure 1: Questionaries' according to age (20 - 39).

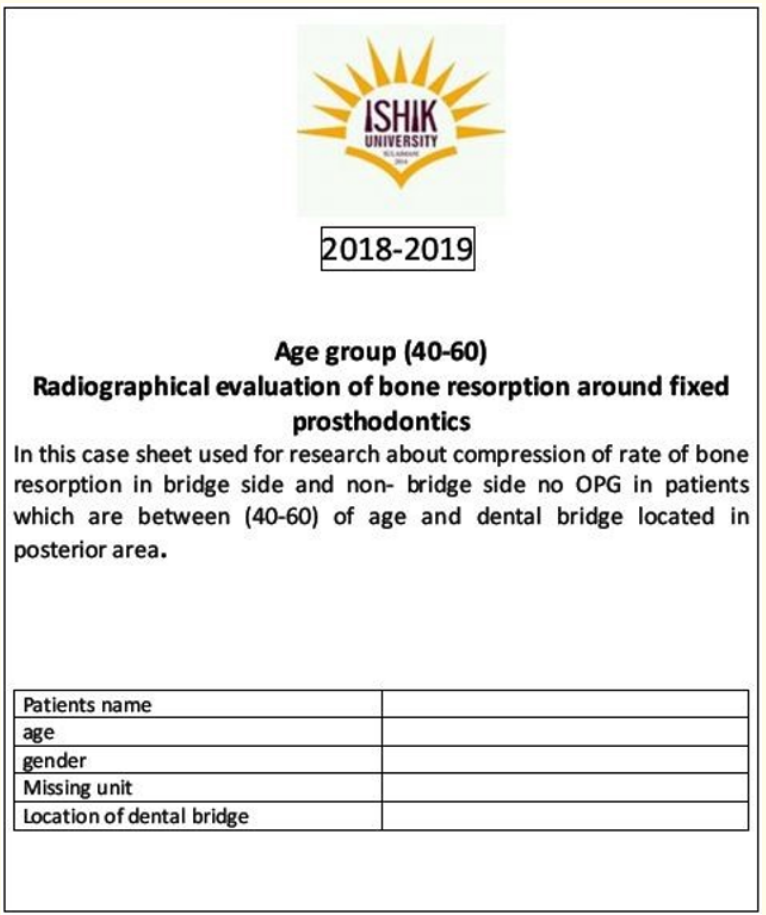

Figure 2: Questionaries' according to age (40 - 60).
- Total filtration: $85 \mathrm{kvp}$

- $\quad$ 2D mode 3.2mmAL-CBCT $6.2 \mathrm{mmAl}$.

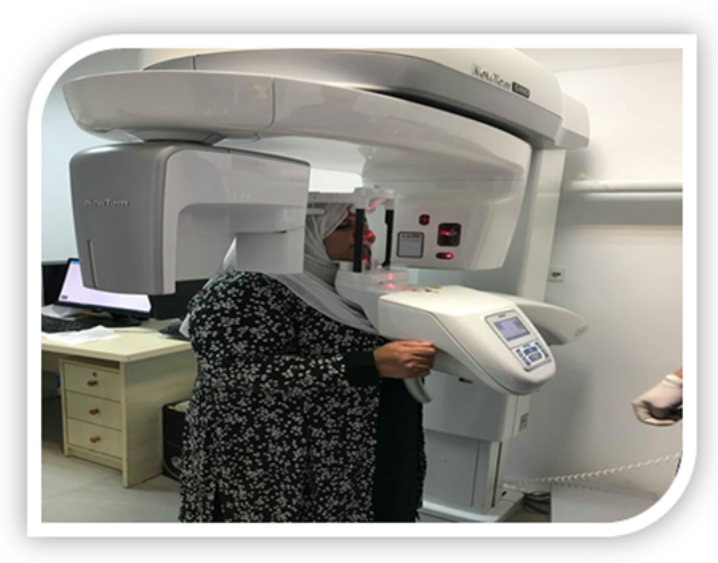

Figure 3: Orthopantogram: NEWTOM.

Using new tom program for measurement and collection data

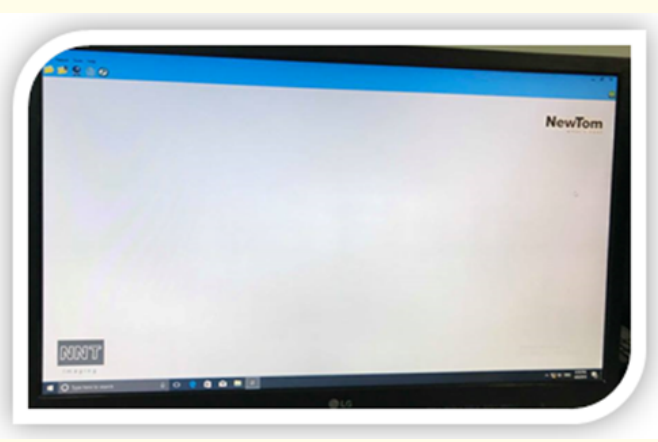

Figure 4: NEWTOM program

OPG of patients with bridge present

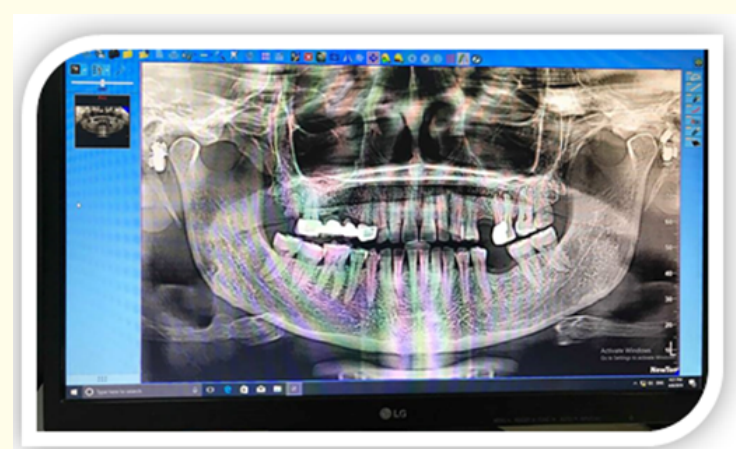

Figure 5: Orthopantogram. 
Measurement of bridge side and non bridge side

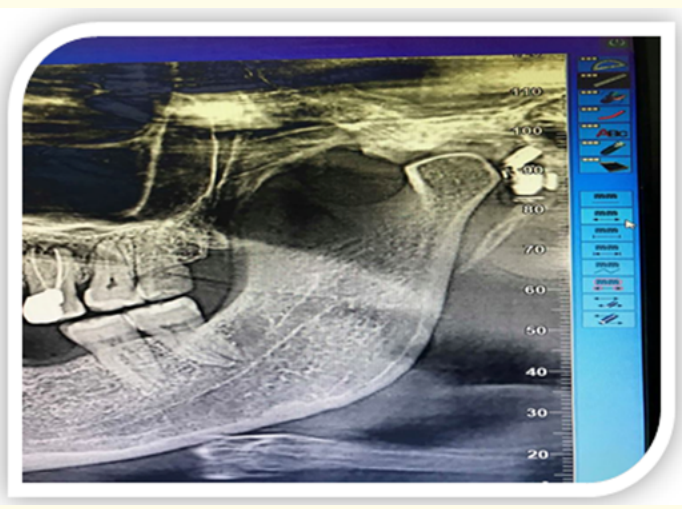

Figure 6: Measurement arrow.

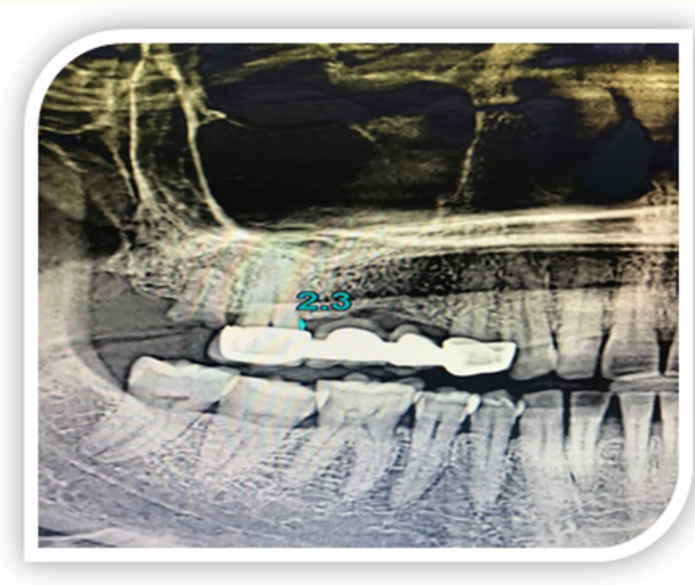

Figure 7: Measurement of bridge site.

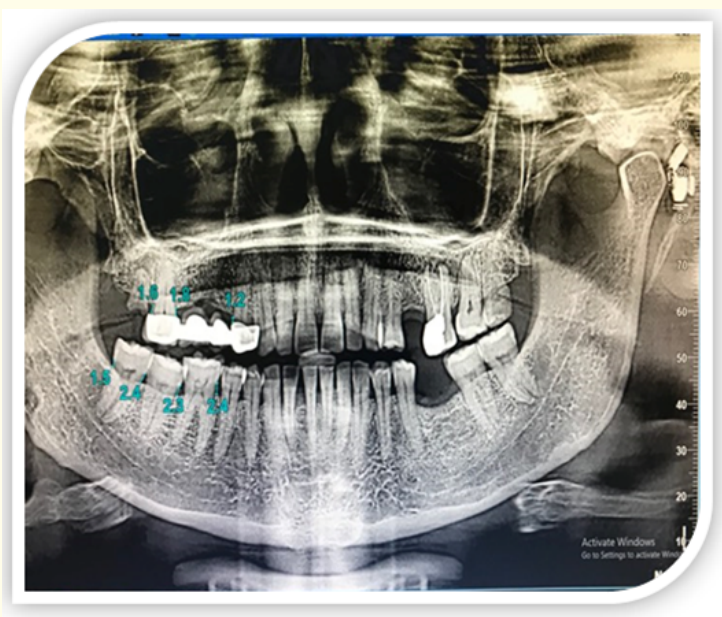

Figure 8

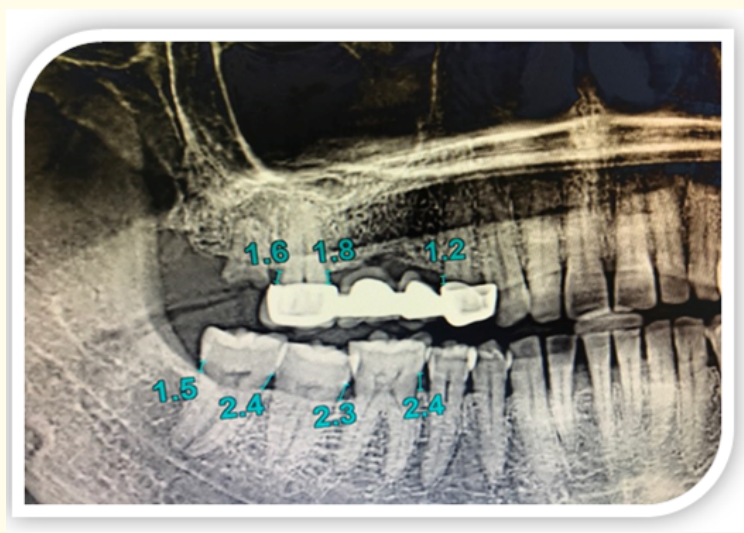

Figure 9: Measurement of bridge side and non-bridge side.

Results

Table 1 indicates that $55.2 \%$ of participants in the study were female and $44.8 \%$ of them were male. Majority (83.8\%) of patients were from the age group of 40-60 years. Most of the participants (65.6\%) had one missing unit and were located in the upper jaw, while most of the non-bridge sites were in the lower jaw.

\begin{tabular}{|l|c|c|c|}
\hline \multicolumn{1}{|c|}{ Variable } & Categories & Number & Percent \\
\hline \multirow{4}{*}{ Sex } & Male & 108 & 44.8 \\
\cline { 2 - 4 } & Female & 133 & 55.2 \\
\hline Age groups (years) & $20-39$ & 39 & 16.2 \\
\cline { 2 - 4 } & $40-60$ & 202 & 83.8 \\
\hline \multirow{5}{*}{ Missing unit } & One & 158 & 65.6 \\
\cline { 2 - 4 } & Two & 83 & 34.4 \\
\hline \multirow{3}{*}{ Bridge site } & Upper right & 72 & 29.9 \\
\cline { 2 - 4 } & Upper left & 74 & 30.7 \\
\cline { 2 - 4 } & Lower left & 35 & 14.5 \\
\cline { 2 - 4 } Non-bridge site & Lower right & 60 & 24.9 \\
\cline { 2 - 4 } & Upper right & 52 & 21.6 \\
\cline { 2 - 4 } & Upper left & 30 & 12.4 \\
\cline { 2 - 4 } & Lower left & 96 & 39.8 \\
\cline { 2 - 4 } & Lower right & 63 & 26.1 \\
\hline \multirow{5}{*}{ Total } & & 421 & 100 \\
\hline
\end{tabular}

Table 1: Descriptive data of participants related to their sex, age, missing units, and site of bridge and non-bridge. 
According to results of table 2, there was a statistically significant difference in bone resorption between bridge and non-bridge sides. The average bone resorption of bridge was $3.15 \mathrm{~mm}$ which is lower than that of non-bridge side ( $3.80 \mathrm{~mm}$ ). T-test was done to compare between the two sides and P-value was 0.001 .

\begin{tabular}{|l|c|c|c|c|c|}
\hline $\begin{array}{c}\text { Bone resorption } \\
\text { (mm) }\end{array}$ & N & Mean & $\begin{array}{c}\text { Std. } \\
\text { Deviation }\end{array}$ & P-value & T-test \\
\hline Bridge side & 241 & 3.15 & 0.94 & 0.001 & Significant \\
\hline Non-bridge side & 241 & 3.80 & 1.24 & & \\
\hline
\end{tabular}

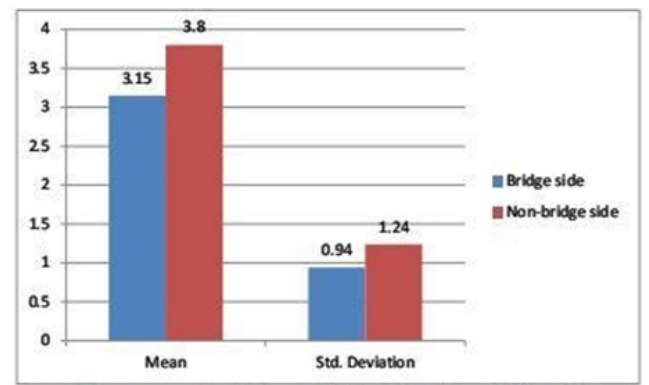

Table 2: Comparison of bone resorption between bridge and non-bridge sides.

The findings of table 3 and 4 reveal that the mean bone resorption of bridge side was lower than that of non-bridge side for both male and female patients.

\begin{tabular}{|l|c|c|c|c|c|}
\hline $\begin{array}{c}\text { Bone resorp- } \\
\text { tion (mm) }\end{array}$ & N & Mean & $\begin{array}{c}\text { Std. } \\
\text { Deviation }\end{array}$ & P-value & T-test \\
\hline $\begin{array}{l}\text { Bridge side } \\
\text { Non-bridge side }\end{array}$ & 108 & 3.52 & 0.99 & 0.002 & Significant \\
\hline
\end{tabular}

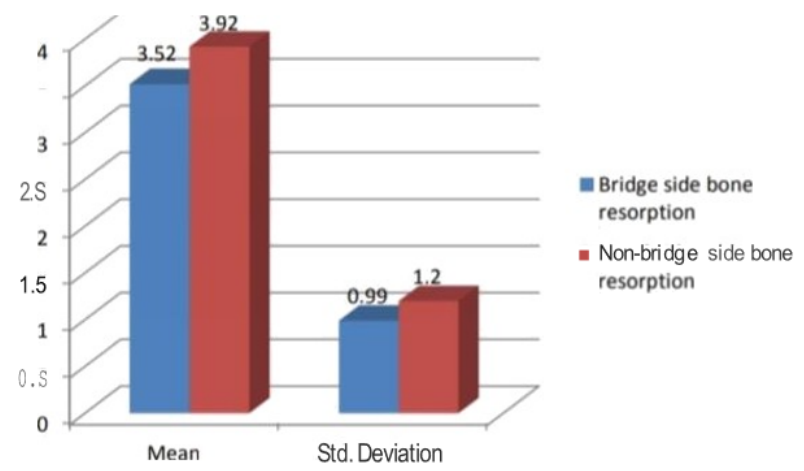

Table 3: Bone resorption of bridge and non-bridge sides for male patients.

\begin{tabular}{|l|c|c|c|c|c|}
\hline $\begin{array}{c}\text { Bone resorption } \\
\text { (mm) }\end{array}$ & N & Mean & $\begin{array}{c}\text { Std. } \\
\text { Deviation }\end{array}$ & P-value & T-test \\
\cline { 1 - 4 } Bridge side & 133 & 2.85 & 0.78 & 0.001 & Significant \\
\cline { 1 - 3 } Non-bridge side & 133 & 3.70 & 1.26 & & \\
\hline
\end{tabular}

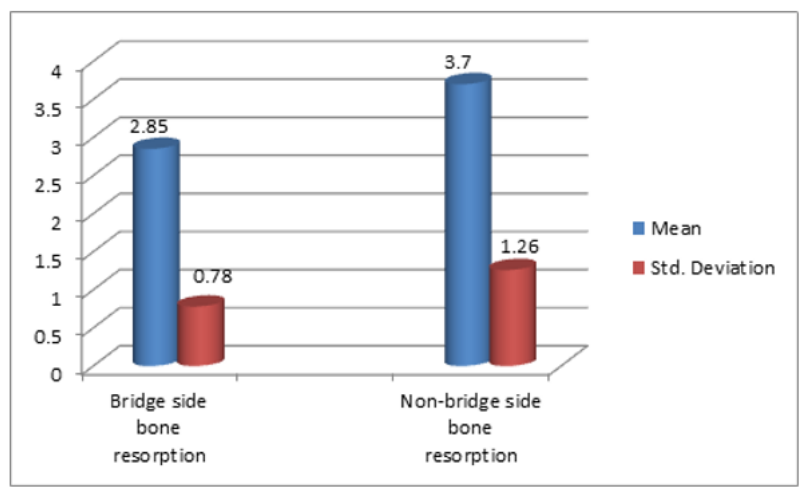

Table 4: Bone resorption of bridge and non-bridge sides for female patients.

The $\mathrm{M}$ from table 5 and row that there was no statically significant difference between both age groups in bridge and P-value 0.72 . Art contrary the difference we significate and the age group 40 - 60 pars had higher bone absorption (mrna 91) compared to 20-39 years age group left have bone of 3.9 mot. P-value of ID1.

\begin{tabular}{|c|c|c|c|c|c|c|}
\hline Side & $\begin{array}{c}\text { Age } \\
\text { (years) }\end{array}$ & $\mathbf{N}$ & Mean & $\begin{array}{c}\text { Std. } \\
\text { Deviation }\end{array}$ & $\begin{array}{c}\text { P- } \\
\text { value }\end{array}$ & T-test \\
\hline \multirow[t]{2}{*}{ Bridge } & $20-39$ & 39 & 3.20 & 1.09 & \multirow[t]{2}{*}{0.73} & \multirow{2}{*}{$\begin{array}{c}\text { Non- } \\
\text { significant }\end{array}$} \\
\hline & $40-60$ & 202 & 3.14 & 0.91 & & \\
\hline \multirow{2}{*}{$\begin{array}{l}\text { Non- } \\
\text { bridge }\end{array}$} & $20-39$ & 39 & 3.19 & 0.97 & \multirow[t]{2}{*}{0.001} & \multirow[t]{2}{*}{ Significant } \\
\hline & $40-60$ & 202 & 3.91 & 1.25 & & \\
\hline
\end{tabular}

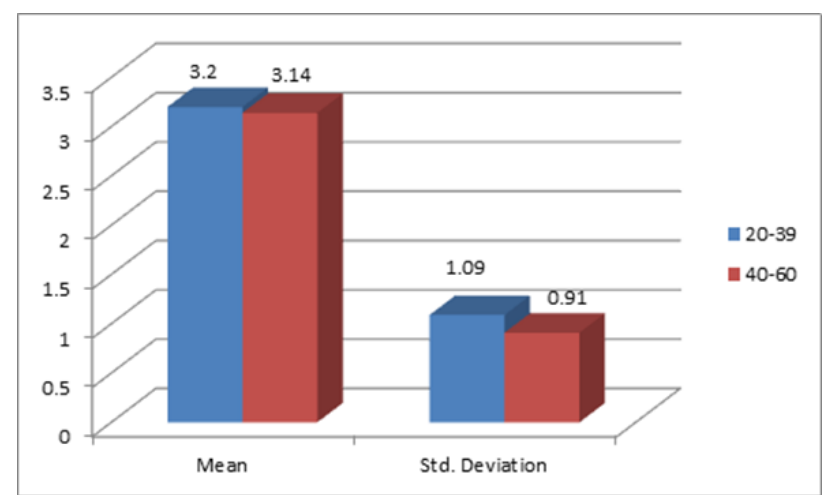




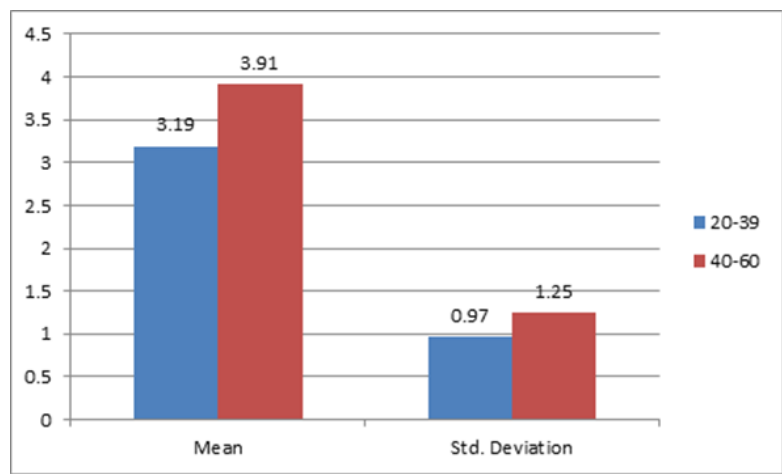

Table 5: Difference in bone resorption of bridge and non-bridge sides according to age groups of the patients.

The findings of table 6 point to very close average bone resorption of both one and two missing units whether in bridge or nonbridge sides. T-tests were done to find out the difference and P-values were more than 0.05 .

\begin{tabular}{|c|c|c|c|c|c|c|}
\hline Side & $\begin{array}{c}\text { Missing } \\
\text { units }\end{array}$ & $\mathbf{N}$ & Mean & $\begin{array}{c}\text { Std. } \\
\text { Deviation }\end{array}$ & $\begin{array}{c}\text { P- } \\
\text { value }\end{array}$ & T-test \\
\hline \multirow[t]{2}{*}{ Bridge } & One & 158 & 3.10 & 0.92 & \multirow{2}{*}{0.23} & \multirow{2}{*}{$\begin{array}{c}\text { Non- } \\
\text { significant }\end{array}$} \\
\hline & Two & 83 & 3.25 & 0.97 & & \\
\hline \multirow{2}{*}{$\begin{array}{l}\text { Non- } \\
\text { bridge }\end{array}$} & One & 158 & 3.75 & 1.28 & \multirow{2}{*}{0.39} & \multirow{2}{*}{$\begin{array}{c}\text { Non- } \\
\text { significant }\end{array}$} \\
\hline & Two & 83 & 3.89 & 1.15 & & \\
\hline
\end{tabular}

Table 6: Difference in bone resorption of bridge and non-bridge sides according to missing unit.

\begin{tabular}{|l|c|c|c|c|c|}
\hline Bridge site & N & Mean & $\begin{array}{c}\text { Std. } \\
\text { Deviation }\end{array}$ & P-value & T-test \\
\hline Upper jaw & 146 & 3.14 & 0.97 & 0.76 & $\begin{array}{c}\text { Non- } \\
\text { significant }\end{array}$ \\
\hline Lower jaw & 95 & 3.18 & 0.90 & & \\
\hline
\end{tabular}

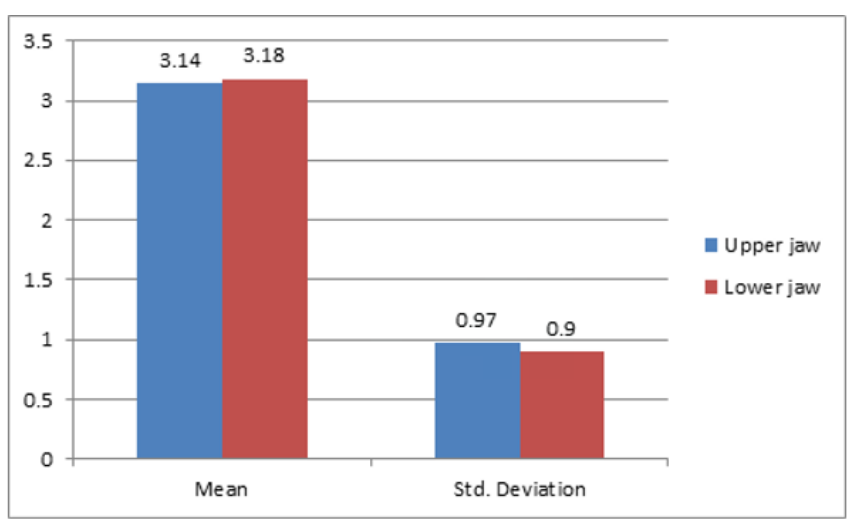

Table 7: Comparison of bone resorption in upper and lower jaws among bridge site.

\begin{tabular}{|l|c|c|c|c|c|}
\hline $\begin{array}{c}\text { Non-bridge } \\
\text { site }\end{array}$ & N & Mean & $\begin{array}{c}\text { Std. } \\
\text { Deviation }\end{array}$ & P-value & T-test \\
\cline { 1 - 4 } Upper jaw & 82 & 3.72 & 1.30 & 0.48 & Non-significant \\
\cline { 1 - 3 } & 159 & 3.84 & 1.21 & & \\
\hline
\end{tabular}

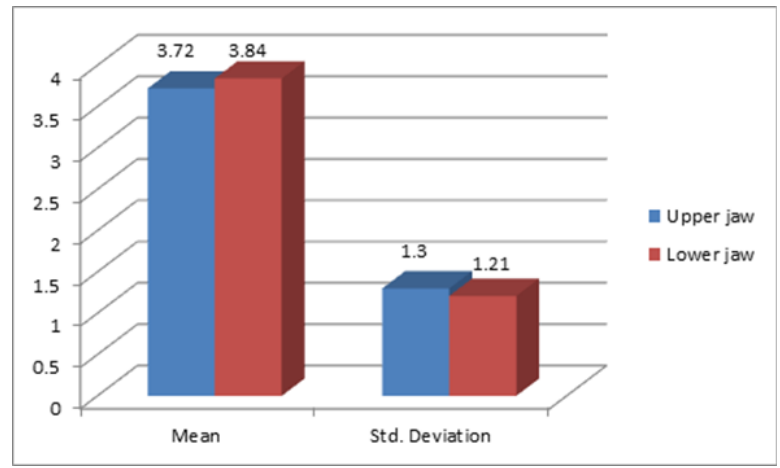

Table 8: Comparison of bone resorption in upper and lower jaws among non-bridge site.

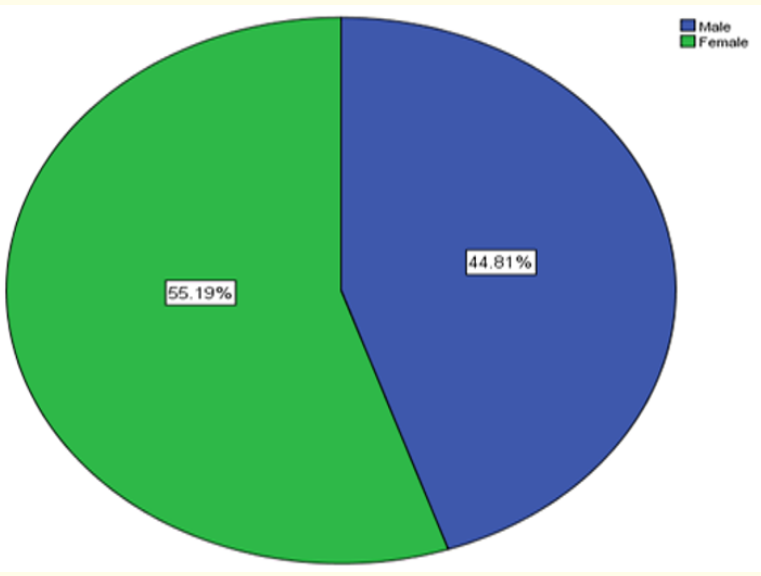

Figure 10

\section{Discussion}

This study concentrate on rate of bone resorption in bridge site and non-bridge site in posterior areas at TIU dental school. In accordance to this research there has not been any related or directly linked certified/verified research references for this scientific research.

\section{Descriptive statistics}

In this study 242 cases about posterior fixed dental bridge had been recorded from total number of cases which have been done 
there were $44.8 \%$ of participants were male and $55.2 \%$ female, according to two age group which were between (20-39)and percentage of participants were $16.2 \%$ and another age group was (40 - 60) and percentage of participants were $83.8 \%$-according to missing unit - percentage of missing unit was 65.6\%, two missing unit were $34.4 \%$-according to site of bridge, upper right $29.9 \%$, upper left $30.7 \%$, lower left $14.5 \%$ lower right $24.9 \%$ - according to non-bridge site, upper right $21.6 \%$ upper left $12.4 \%$, lower right $26.1 \%$.

\section{Inferential statistics}

\section{Comparison of bone resorption}

Comparison of bone resorption between bridge and non-bridge side: According to results, there was a statistically significant differences in bone resorption between bridge and non-bridge sides the average of bone resorption of bridge was $3.15 \mathrm{~mm}$ which is lower than of non-bridge site $(3.80 \mathrm{~mm}) \mathrm{T}$-Test was done to compare between two site, and P-value was 0.001 .

Bone resorption of bridge and non-bridge side for male patients

According to results, there was a statistically significant differences in bone resorption between bridge side and non-bridge side in male the average of bone resorption of bridge was $(3.52 \mathrm{~mm})$ which is lower than that of non-bridge site (3.92 mm) T-Test was done to compare between tow site and P-Value 0.002 .

Bone resorption of bridge and non-bridge sites female patients

According to results, there was a statistically significant differences in bone resorption between bridge side and non-bridge side in female average of bone resorption in bridge site was $(2.85 \mathrm{~mm})$ which is lower than that of non-bridge site $(3.70 \mathrm{~mm})$. T-Test Value done to compare between two sides and P-value 0.001 .

Difference in bone resorption of bridge and non-bride side according to age group of the patients

There was no statistically significant difference between both age groups in bridge side. The average of bone resorption in age group (20 - 39) was (3.20 mm) which was a little bite higher than second age group which were $(40-60)$ and was $(3.14 \mathrm{~mm})$ and P-Value was (0.73). In contrary differences was significance, the age group (40 - 60) years had higher bone resorption (3.91 mm) compare to (20 - 39) years age group had mean bone resorption of (3.19 mm) P-value was 0.001. T-test value done to compare between two sites.

Difference in bone resorption of bridge side and non-bridge site according to missing unit

The findings pointed to very close average bone resorption of both and two missing units whether in bridge or non-bridge sides. In bridge side average of one missing unit is $(3.10 \mathrm{~mm})$ and in tow missing units ( $3.25 \mathrm{~mm})$ and T-test done to compare between tow missing units area and P-value (0.23) which is higher than (0.05). In non-bridge side the average of one missing unit was $(3.75 \mathrm{~mm})$ while the average in tow missing unit was $(3.89 \mathrm{~mm})$ and also Ttest was done to compare between tow missing area and P-value (0.39) which is more than (0.05).

Comparison bone resorption in upper and lower jaws among bridge sides

The findings pointed to very close average bone resorption of both and tow missing units whether in bridge or non-bridge sides. In bridge side average of one missing unit is $(3.10 \mathrm{~mm})$ and in tow missing units (3.25 $\mathrm{mm}$ ) and T-test done to compare between tow missing units area and P-value (0.23) which is higher than (0.05). In non-bridge side the average of one missing unit was $(3.75 \mathrm{~mm})$ while the average in tow missing unit was $(3.89 \mathrm{~mm})$ and also Ttest was done to compare between tow missing area and P-value (0.39) which is more than (0.05).

Comparison bone resorption in upper and lower jaws among bridge sides

The findings reveal that there were no statistically significant differences in mean bone resorption of upper and lower jaws in bridge side. The average of upper jaw was $(3.14 \mathrm{~mm})$ while the average of bone resorption in lower jaw $(3.18 \mathrm{~mm})$. T- test value has been done to compare between tow side-value (0.75).

\section{Compare to other studies}

Rehmann., et al. [4] found that the patient s complaint is important factor in the successful operation of long-span fixed dental prosthesis which does not meeting Ante's law. The outcomes demonstrate that the patient's consistence is a critical factor in the effective usage of a LSFDP, while different variables are of minor significance. 
Clinical oral implant found that long term fixed dental prosthesis with an abutment that has seriously decrease periodontal support relies upon the support of a healthy periodontium [1]. With well-maintained, healthy periodontal tissue support, FDPs does not satisfying Ante's law have survival rates comparable with the high rates of FDPs that do satisfy Ante's law. Therefore, the design of an FDP does not necessarily have to satisfy Ante's law [1]. Anti's law express that total residual area of abutment teeth should be equal or more than tooth or teeth that should be replaced for over 80 years this law has been educated in standard Course reading of prosthesis as a significant condition affecting FDP design so FDP upheld by abutment have sound periodontal bone support would be protected for natural and clinicians to consider. The present study compare bone resorption around abutment teeth in bridge one and two unit missing area, the result does not show any significant differences between the two groups.

\section{Conclusion}

1. Comparison of bone resorption between bridge and nonbridge side is significant.

2. Comparison of bone resorption of bridge and non-bridge sides for male patients is significant.

3. Comparison of bone resorption of bridge and non-bridge sides for female patients is significant.

4. Difference of bone resorption in bridge side according to age groups is non-significant.

5. Difference of bone resorption in non-bridge side according to age groups is significant.

6. Difference in bone resorption in bridge side according to missing unit is non-significant.

7. Difference in bone resorption in upper and lower jaw among bridge side is non-significant.

8. Difference in bone resorption in upper and lower jaws in non-bridge side is non-significant.

\section{Suggestion}

1. Further studies are needed for investigation effect of oral hygiene around abutment teeth in fixed bridge.

2. Further studies are needed for investigation effect of smoking on rate of success of dental bridge, and bone resorption.
3. Further studies are needed for finding effects of systemic disease on rate of bone resorption and successful rate of dental bridge

4. Further studies are needed for investigation presence of bridge in anterior region and comparison of rate of bone resorption with other sites.

5. Further studies are needed for investigation, if missing teeth were more than 2 unit and effect of it on rate of bone resorption.

6. Further studies are needed for investigation presence of dental implant as abutment and comparison rate of bone resorption with the tooth supporting dental bridges.

7. Further studies are needed about the materials (metal, ceramic, and zircon) that used for dental bridge and effect of it on bone resorption.

\section{Bibliography}

1. Lulic M., et al. "Ante's (1926) law revisited: a systematic review on survival rates and complications of fixed dental prostheses (FDPs) on severely reduced periodontal tissue support". Clinical oral Implants Research 18.3 (2007): 63-72.

2. Rosenstiel SF., et al. "Contemporary fixed prosthodontics $\left(4^{\text {th }}\right.$ Edition)”. St. Louis: Mosby (2006).

3. Gopakumar A and Boyle EL. "A bridge too far'--the negative impact of bridge prosthesis on gingival health and its conservative management". British Dental Journal 215.6 (2013): 273276.

4. Mitchell David and Laura. "Oxford Handbook of Clinical Dentistry". Oxford (2016).

5. Mitchell DA., et al. "Oxford Handbook of Clinical Dentistry (Sixth Edition.)”. Oxford: Oxford University Press (2014): 268.

6. Bishop K., et al. "Modern restorative management of patients with congenitally missing teeth: 3 . Conventional restorative options and considerations". Dental Update 34.1 (2007): 3032.

7. Maglad AS., et al. "Risk management in clinical practice. Part 3. Crowns and bridges”. British Dental Journal 209.3 (2010): 115. 
8. Briggs P., et al. "Avoiding and managing the failure of conventional crowns and bridges". Dental Update 39.2 (2012): 78-80.

9. Bartlett D and Ricketts D. "Advanced operative dentistry: a practical approach". Edinburgh: Elsevier Churchill Lvgst (2013).

10. Kc Basnyat S., et al. "Oral Hygiene and Gingival Health in Patients with Fixed Prosthodontic Appliances - A Six Month Follow-up". Kathmandu University Medical Journal 13.52 (2015): 328-332.

11. Ortolan SM., et al. "Oral hygiene and gingival health in patients with fixed prosthodontics appliances--a 12- month follow-up". Collegium Antropologicum 36.1 (2012): 213-220.

12. Walmsley AD. "Restorative dentistry". Churchill Livingstone (2007).

\section{Assets from publication with us}

- Prompt Acknowledgement after receiving the article

- Thorough Double blinded peer review

- Rapid Publication

- Issue of Publication Certificate

- High visibility of your Published work

Website: www.actascientific.com/

Submit Article: www.actascientific.com/submission.php

Email us: editor@actascientific.com

Contact us: +919182824667 